\title{
WHAT DO PEOPLE WANT FROM THEIR COMMUNITY FORESTS? RESULTS OF A PUBLIC ATTITUDE SURVEY IN MISSOURI, U.S.
}

\author{
By Thomas Treiman ${ }^{1}$ and Justine Gartner ${ }^{2}$
}

\begin{abstract}
A self-administered survey of randomly selected recipients in 44 Missouri, U.S., communities found that most Missourians were very concerned about the quality of natural resources and having trees on streets and in parks. Respondents felt that Missouri was not doing well at making sure fewer trees are lost during development and at managing stormwater runoff. Residents in communities with a population of 50,000 or more, in the St. Louis and Kansas City suburbs, and in the cities of St. Louis and Kansas City show strong support for a ballot issue establishing a tree fund supported by a tax of US\$5 or less. Missourians in communities with a population greater than 5,000 showed support for protecting or replacing trees during development through passage of a tree preservation ordinance. They lack basic knowledge of their community's tree program and could not correctly say whether their community was certified by The National Arbor Day Foundation as a Tree City USA. They are most likely to seek information on trees from their local garden center. The results of the survey, together with recent surveys of community forestry officials and street tree inventories, are used to make recommendations to state agencies charged with managing community forests.

Key Words. Missouri, U.S.; public attitude; survey research; tree program; urban and community forestry.
\end{abstract}

The Community Forestry Program, administered by the Missouri Department of Conservation (MDC), is designed to advise, coordinate, and facilitate the efforts made by many jurisdictions and entities that own and affect the state's community forests. MDC foresters help communities and individuals effectively manage the trees that make up their community or urban forest. Managing these resources can help improve the environmental, social, and economic well being of each community and ultimately the entire state of Missouri.

MDC employs seven individuals who are specifically titled urban foresters (in addition, community forestry assistance is provided by all Forestry Division foresters) and annually spends approximately US\$440,000 (over and above salaries) in support of the Community Forestry Program. MDC foresters provide assistance to local and regional governments and to individuals, developers, the nursery industry, or anyone with an interest in managing community trees. They also support an annual community forestry cost-share program called Tree Resource Improvement and Maintenance (TRIM). Foresters advise on the development of tree care programs, municipal tree ordinances, and tree boards, and proper location of new trees. Tree plans are provided for public property such as parks, schools, streets, and building grounds.

In order for MDC to provide better and more targeted service to communities and local governments to help them manage their urban forest resource, the agency identified the need for a better understanding of urban forest resources, how they are managed, and how they and their management is viewed by Missouri citizens. To this end, MDC has conducted two urban tree inventories on plots in 44 Missouri towns in 1989 and 1999 (Rocca 1992; Gartner et al. 2002). The 1999 survey was one of the first follow-up surveys done by any state. A comparison of data shows significant changes in Missouri's community forests. Communities have more trees, but their condition declined. Missouri's urban forests are becoming more diverse (Gartner et al. 2002). The top six tree species constituted $37 \%$ of those surveyed in 1999, as compared to 53\% found in 1989. The average value of a Missouri street tree increased \$642, using the Council of Tree \& Landscape Appraisers' formulas (CTLA 1992). Other studies across the nation have also focused on the physical inventory of urban trees (Baker 1993). Nowak et al. (2001), for example, found that urban areas in the United States contain approximately 3.8 billion trees with an average tree canopy cover of $27 \%$.

In addition, MDC conducted a mail survey of local government officials responsible for tree planting, care, and maintenance in 602 communities across the state (Treiman and Gartner 2004). Results of this survey indicate that tree activities in most communities are funded primarily from general revenue, making information on creative funding strategies vital to creating sustainable community forestry programs. Most communities were characterized as reactive in caring for their community forest, with the majority budgeting no dollars for tree care activities. Seventy-five percent of the communities surveyed indicated that they do not have a single full-time person employed who spends the majority of his or her time performing tree-related activities. This makes a focused and methodical approach to tree care and the elimination of hazardous trees difficult. It also reinforces the need to provide training on basic topics. Responsibility for tree care rests in a variety of departments, 
depending on the community. Consequently, requests for assistance could potentially come from multiple departments within a community, making it difficult to deliver targeted and coordinated assistance.

Most Missouri communities do not have a public tree ordinance, a written community forest management plan, or a comprehensive tree ordinance that addresses tree preservation during development. This points to the need for greater publicity of the value of trees, the value of planning for proper care, and the necessity to educate communities that trees are a part of a community's infrastructure. Communities with a population less than 5,000 are less likely to utilize cost-share programs available through MDC. Communities that are willing to budget for tree care activities or that have a public tree ordinance are more likely to participate in state cost-share programs. The majority of community officials feel that basic tree maintenance activities, such as removal of hazardous trees and tree pruning, are important.

Community forestry officials in Missouri, at both the local and state level, lack specific, systematic information on what the public actually knows about their urban forest resource, what they want from it, and how important it may be to them. The third phase of this evaluation of Missouri's community forests was to survey citizens across the state to answer some of those questions.

\section{METHODS}

A survey was designed and tested that included questions asking respondents to rank their attitudes toward certain community forestry issues, such as hazard trees, topping, and urban sprawl. Respondents were also asked about Tree City USA status, where they would go for advice on urban forestry issues, and which department(s) of their local government was responsible for tree care and maintenance. Respondents were asked how they would vote on two hypothetical ballot questions: Would they be willing to pay a tax of varying levels to fund tree care and maintenance, and would they support establishing a new law to protect trees during development. Finally a set of demographic questions was included.

One measure of the importance of urban forests and community forestry programs is quite simple: How much would people be willing to pay for them? Based on focus groups and pre-tests, the survey was printed in seven different versions, each with a different tax level in the question asking whether respondents would be willing to pay a tax to fund tree care and maintenance. Respondents received a survey form asking whether they would pay a tax of $\$ x$, where $x$ was one value randomly selected from the set $\$ 1, \$ 3, \$ 5, \$ 7, \$ 10, \$ 15$, or $\$ 20$ (U.S. dollars). These figures were pre-tested with a focus group. Interesting information (and more accurate estimates) might have been gained by adding unrealistically high values to the question set (say $\$ 100$ or $\$ 500$ ), but this was felt to be politically unfeasible for a survey mailed out by a state agency. This method, referred to in economic literature as the contingent valuation method (CVM), allows the calculation of the population's mean willingness-to-pay (WTP) for public tree care and maintenance. Mitchell and Carson (1989) developed detailed guidelines for properly implementing CVM that are now widely followed and accepted, while Boyle (2003) has outlined appropriate analysis methods.

The survey was designed to test for differences across different "size" communities (strata) within Missouri. The first six strata are defined by the population of the community, while the last four are reserved for specific communities in St. Louis, Kansas City, and their suburbs (Table 1).

A mailing list of 18,347 randomly selected names was purchased from USADATA. Respondents were randomly asked about one of the tax levels listed above. The mailings followed Dillman's (2000) methodology and were conducted between March and May 2004. The overall response rate for the mailing list was $40 \%$. This response rate is within the normal range for self-administered mail surveys. Response rates to such surveys have declined appreciably over the last 30 years, with the "average" mail survey obtaining a response rate of around $65 \%$ in the 1970 s but only around $45 \%$ by the year 2001 (Baruch 1999; Connelly et al. 2003).

Table 1. Survey strata: The survey was designed for analysis by each group (strata). Strata were defined by community size (1-6) or location (7-10).

\begin{tabular}{ll}
\hline Survey strata & Population/location \\
\hline 1 & Less than 5,001 \\
2 & Between 5,001 and 10,000 \\
3 & Between 10,001 and 20,000 \\
4 & Between 20,001 and 50,000 \\
5 & Between 50,001 and 150,000 \\
6 & Between 150,001 and 250,000 \\
7 & St. Louis suburbs \\
8 & Kansas City suburbs \\
9 & St. Louis \\
10 & Kansas City \\
\hline
\end{tabular}

\section{RESULTS AND DISCUSSION Natural Resource Issues and Community Forestry Programs}

Respondents were asked how important a set of issues were to them and also how well they thought Missouri was doing at addressing those same issues. All the issues were ranked as "important" or "very important" by the vast majority of respondents (Table 2), but significantly fewer respondents thought that Missouri was doing "very well" or "well" at addressing tree loss during development and stormwater runoff. This contrasts with findings by Lorenzo et al. (2000), 
who found that a large majority of small-city respondents in one Louisiana community felt that their community's performance in tree protection and maintenance was "good to excellent." The dissonance between the high ranking that Missourians gave to natural resources and how well they felt Missouri was doing at addressing those issues may show where the public would like to see more effort placed, and provide an opening for public education programs.

Respondents were also asked how important it was to have various items as part of the community forestry program run by their community. Managing hazard trees received the highest total of "very important" or "somewhat important" responses (93\%), closely followed by tree planting (92\%) and tree maintenance (92\%). A smaller percentage, 59\% of respondents, thought that tree inventory was important (Table 3 ). Note that respondents were not told about the costs of these items or any trade-offs between items, so responses represent a "pie-in-the-sky" ideal program.

Sixty-one percent of respondents agreed ("strongly" or "somewhat") that public trees in their community were in

Table 2. Comparison of issue importance and issue success. Percentages represent the total of respondents answering either "very important" or "somewhat important," and the total of respondents answering either "very well" or "well" $\left(\chi^{2}=29737.1\right.$, DF 6 , $P<0.0001$ ).

\begin{tabular}{lll}
\hline $\begin{array}{l}\text { Issue } \\
\begin{array}{l}\text { Quality of } \\
\text { natural resources }\end{array}\end{array}$ & $\begin{array}{l}\text { Responding } \\
\text { "important" }\end{array}$ & $\begin{array}{l}\text { Responding } \\
\text { doing "well" }\end{array}$ \\
$\begin{array}{l}\text { Having trees on } \\
\text { streets and in parks }\end{array}$ & $67 \%$ \\
$\begin{array}{l}\text { Making sure fewer trees } \\
\text { are lost during development }\end{array}$ & $88 \%$ & $76 \%$ \\
Managing stormwater runoff & $92 \%$ & $28 \%$ \\
\hline
\end{tabular}

Table 3. Percentage of respondents saying that a component was a "very important" or "somewhat important" part of a community forestry program $\left(\chi^{2}=15211.1, \mathrm{DF}\right.$ 6, P $<0.0001)$.

\begin{tabular}{ll}
\hline Program component & Responding "important" \\
\hline $\begin{array}{l}\text { Planting trees } \\
\text { Caring for new trees after planting }\end{array}$ & $92.1 \%$ \\
$\begin{array}{l}\text { Having a tree law that defines the } \\
\text { community's responsibility for }\end{array}$ & $59.9 \%$ \\
$\begin{array}{l}\text { tree care and maintenance } \\
\text { Counting, measuring, and }\end{array}$ & $59.7 \%$ \\
$\begin{array}{l}\text { monitoring trees } \\
\text { Pruning for tree shape and safety }\end{array}$ & $85.8 \%$ \\
$\begin{array}{l}\text { Removing trees that might break } \\
\text { and cause injury or property damage }\end{array}$ & $93.0 \%$ \\
\hline
\end{tabular}

good condition, and only 21\% saw hazard trees as a problem in their communities. Slightly more respondents (28\%) thought their communities had enough public trees than disagreed (27\%), with 29\% being "neutral" and 14\% saying they did not know. About $73 \%$ said that trees counted as "community assets." Over 60\% said that their community was a better place to live thanks to public trees. Except for hazard trees, this study did not break down specific costs and benefits related to urban trees, as did work by, for example, Lohr et al. (2004), but respondents in the focus groups used to test the survey noted many of the same benefits that Lohr et al. did (e.g., shade, aesthetics, and pollution control).

Respondents were asked which from a list of departments were responsible for tree care in their towns. For all the possibilities on the list except "Parks \& Recreation," "do not know" was the highest response. (For "Parks \& Recreation," $53 \%$ said "yes" it was responsible, while $41 \%$ said "do not know.") The plurality of respondents did not know whether their communities provided enough resources (employees, money, and equipment) to manage trees (27\%) or whether their communities were doing enough to protect trees during development (23\%). Only 11\% thought that people in their communities would be willing to pay more in taxes for better tree care. $\left(\chi^{2}=10303.2, \mathrm{DF}=6, P<0.0001\right)$.

\section{The Hypothetical Tree Fund}

Across all ten strata, respondents were willing to vote yes on the hypothetical ballot issue to establish a tree care fund (Table 4). Overall, 53\% of respondents said that they would vote yes. In general, more people responded positively in larger communities or those around major cities (i.e., the St. Louis and Kansas City suburbs). This trend may reflect either a greater awareness of the need for such a fund in larger communities or a greater willingness to turn to the government to solve those problems. The response to the range of hypothetical taxes that would support the tree fund makes economic sense: As the level of tax rises, the level of support decreases. Still, even at the highest hypothetical tax level (\$20), more respondents (43.8\%) said they would vote yes than said no $(26.5 \%)\left(\chi^{2}=165.6, \mathrm{DF}=18, P<0.0001\right)$.

Respondents were also asked to choose from a list of statements those which most influenced their "vote." The leading reasons chosen (overall) were "amount of the tax," "community responsibility for trees," and "condition of trees in my community." Again, basing one's "vote" on the level of proposed tax makes economic sense. The other two popular reasons give insight into how people think about their community's trees and their importance. It is interesting to note that "yes" voters were far more likely than "no" voters to list "community responsibility for trees" and "condition of trees in my community" as important reasons, while "no" voters were far more likely than "yes" voters to 
Table 4. Estimated willingness-to-pay (WTP) per household by strata, with $95 \%$ confidence interval. The overall value is derived from the weighted average values.

\begin{tabular}{lcrr}
\hline Strata & WTP estimate & \multicolumn{2}{c}{$95 \%$ confidence limits } \\
\hline Less than 5,001 & $\$ 0.27$ & -7.1714 & 7.7079 \\
Between 5,001 and 10,000 & $\$ 4.56$ & -2.5242 & 11.6349 \\
Between 10,001 and 20,000 & $\$ 8.12$ & 0.9479 & 15.2932 \\
Between 20,001 and 50,000 & $\$ 4.55$ & -2.1668 & 11.2662 \\
Between 50,001 and 150,000 & $\$ 15.47$ & 8.6045 & 22.3339 \\
Between 150,001 and 250,000 & $\$ 14.02$ & 7.1761 & 20.8734 \\
St. Louis suburbs & $\$ 18.86$ & 11.6397 & 26.0708 \\
Kansas City suburbs & $\$ 13.10$ & 6.1119 & 20.0863 \\
St. Louis & $\$ 15.64$ & 6.7245 & 24.5484 \\
Kansas City & $\$ 16.81$ & 8.7434 & 24.8706 \\
Overall & $\mathbf{\$ 1 1 . 0 2}$ & $\mathbf{8 . 7 3 4 0}$ & $\mathbf{1 3 . 3 2 0 6}$ \\
\hline
\end{tabular}

note "trust in government" and "other community priorities/needs" ( $\left.\chi^{2}=6076.5, \mathrm{DF}=3, P<0.0001\right)$.

Survey results were also used to estimate respondents' willingness-to-pay (WTP) by strata (Treiman and Gartner 2005). Citizens' WTP for a tree fund is noticeably higher in and around Missouri's urban areas than in its smaller communities. (Indeed in some of the smaller communities, such as those with fewer than 5,000 residents, we cannot say that WTP is different than zero with a 95\% confidence level.) These larger, more metropolitan communities may have more politically active citizens, better informed citizens, or citizens who simply have higher expectations of government services. These citizens seem willing to fund those expectations. Smaller communities may be more used to lower levels of services, or perhaps more used to fixing problems, including problems with trees, without government aid.

These results from Missouri can be compared to other efforts to determine the value of urban trees. Lorenzo et al. (2000) found, using different methods, that the plurality of residents of one small city were willing to pay between $\$ 6$ and $\$ 12$, which is the same range as for some of the Missouri results. Other authors have estimated residents' willingness to pay for the recreation benefits that wooded areas provide, and found these values to be greater than zero (see Kwak et al. 2003; Tyrväinen and Väänänen 1998; and Dwyer et al. 1989).

\section{Demographics and the Tree Fund Vote}

Younger respondents (ages between 20 and 35) were more likely to vote for the hypothetical tree fund, with those over 65 the least likely. This may be explained by the long-term nature of forestry. Younger voters may be more likely to see the results of their votes. Similarly, respondents who had lived at their current address for a shorter period were more willing to vote for the tree fund than those who had lived there for more than 25 years. Willingness to support the fund increased with both education and income. The latter is unsurprising, as more wealthy voters have more money to contribute to causes in which they believe. It is in line with
Lorenzo et al.'s (2000) results from Louisiana. Men and women voted for and against the hypothetical tree care fund at about the same rate. Lorenzo et al. found, in one small city in Louisiana, that women were more likely to say that they would pay more than men. Those who grew up in suburban areas were most likely to support the fund, with those from rural areas the least likely. Those who now live in suburban or urban areas were the most likely $\left(\chi^{2}=28.0119, \mathrm{DF}=18\right.$, $P<0.0619)$.

\section{Tree Ordinance}

When asked whether they would vote for a tree preservation ordinance (to protect or replace trees during development), a majority of respondents chose "yes" across all strata. Overall, 63\% percent said they would vote "yes." Again citizens in the larger, more urban communities were more likely to "vote" for the ordinance, but it would, hypothetically, have passed in all communities. This difference between metropolitan communities and smaller ones may again be based on differing citizen expectations from government in different sized communities $\left(\chi^{2}=\right.$ 5449.7, $\mathrm{DF}=3, \mathrm{P}<0.0001$ ).

Again, respondents were also asked to choose from a list of statements those which most influenced their "vote." The leading reasons chosen were "property values," "help with stormwater runoff," and aesthetics ("trees are nice/pretty"). In other words, respondents saw trees as both a benefit to themselves and to their entire community. "Yes" voters were far more likely than "no" voters to list "property values," "help with stormwater runoff," and aesthetics as important reasons. "No" voters were far more likely than "yes" voters to consider "development costs," "trust in government," and the clarity of the referendum in their decisions $\left(\chi^{2}=2963.6\right.$, DF $=3, P<0.0001$ ).

\section{Demographics and the Tree Ordinance Vote}

Women were more likely than men to say that they would vote in support of the proposed tree ordinance, with younger voters also more in favor. Support increased with both education and income (although support by income dropped off a little at the highest income level). Those who had lived at their current address for less than 5 years were more likely to support the ordinance than those who had lived there for over 25 years. Those who owned their own home were also more likely to support the ordinance. Respondents who reported that they had grown up in urban or suburban areas were the most likely "yes" voters $\left(\chi^{2}=158.9692, D F=12, P<0.0001\right)$. This may reflect some similarities to Dickerson et al.'s (2001) findings from Illinois that communities with higher income and education levels (such as suburban communities) were more likely to have stronger tree ordinances. 


\section{Tree City USA}

Tree City USA, sponsored by The National Arbor Day Foundation in cooperation with the USDA Forest Service and the National Association of State Foresters, provides direction, technical assistance, public attention, and national recognition for urban and community forestry programs in towns and cities that are home to more than 93 million people in the United States. To qualify as a Tree City USA, a community must have: (1) a tree board or department, (2) a tree care ordinance, (3) a community forestry program with an annual budget of at least $\$ 2$ per capita, and (4) an Arbor Day observance and proclamation (National Arbor Day Foundation 2005).

Of the 44 communities that were included in the questionnaire's mailing list, 20 had qualified as a Tree City USA. Because publicity is one of the four Tree City USA standards, we asked respondents whether their community was a Tree City USA. In Table 5, the column headed "Right" indicates the percentage of respondents who were correct (answering "yes" if they lived in a Tree City USA community or "no" if they did not), while the column headed "Wrong" indicates the percentage of those answering "no" if they lived in a Tree City USA community or "yes" if they did not. The column headed "Tree City" breaks down each strata into communities that were/were not a Tree City USA and indicates how many communities fell into each category. Note that all communities in the survey with populations between 20,001 and 250,000 (as well as St. Louis and Kansas City) were a Tree City USA. The vast majority of respondents did not know whether they lived in a Tree City USA, and, of those who thought that they knew, many answered incorrectly. In general, residents of smaller communities were somewhat more likely to answer correctly $\left(\chi^{2}=\right.$ 748.8, $\mathrm{DF}=38, P<0.005)$.

\section{CONCLUSIONS}

When seeking public support for the management of a community's tree infrastructure, understanding the public's needs, desires, and knowledge is essential. Elmendorf and Luloff (2001) found that the "concerns, beliefs, attitudes, and behaviors of some people continue to be misstated, unknown, and ignored"-leading to failures in community forest planning and management. They recommend better collection and use of unbiased public attitude data and that communication between the public and urban forestry officials go in both directions.

The information from this survey in Missouri is a step in both directions. By following standard survey methodology, unbiased information was collected. This information can be used to develop a communications and education plan
Table 5. Percentage of respondents correctly identifying their communities as Tree City USA/Not Tree City USA, by strata.

\begin{tabular}{lllll}
\hline Strata & Tree City & Right & Wrong & Did not know \\
\hline Less than 5,001 & Yes (1) & $40.00 \%$ & $9.33 \%$ & $50.67 \%$ \\
& No (9) & $20.53 \%$ & $9.02 \%$ & $70.45 \%$ \\
Between 5,001 and 10,000 & Yes (2) & $22.81 \%$ & $9.94 \%$ & $67.25 \%$ \\
& No (5) & $14.41 \%$ & $9.25 \%$ & $76.34 \%$ \\
Between 10,001 and 20,000 & Yes (3) & $36.30 \%$ & $8.52 \%$ & $55.19 \%$ \\
& No (4) & $18.94 \%$ & $7.45 \%$ & $73.60 \%$ \\
Between 20,001 and 50,000 & Yes (2) & $8.27 \%$ & $8.71 \%$ & $83.02 \%$ \\
Between 50,001 and 150,000 & Yes (2) & $10.68 \%$ & $5.84 \%$ & $83.48 \%$ \\
Between 150,001 and 250,000 & Yes (1) & $16.54 \%$ & $7.28 \%$ & $76.18 \%$ \\
St. Louis suburbs & Yes (6) & $25.18 \%$ & $7.44 \%$ & $67.38 \%$ \\
Kansas City suburbs & No (3) & $4.38 \%$ & $43.80 \%$ & $51.82 \%$ \\
& Yes (2) & $15.74 \%$ & $6.79 \%$ & $77.47 \%$ \\
St. Louis & No (2) & $10.60 \%$ & $8.94 \%$ & $80.46 \%$ \\
Kansas City & Yes (1) & $14.15 \%$ & $11.37 \%$ & $74.48 \%$ \\
\hline
\end{tabular}

with a schedule of implementation. Residents do not know the extent of their community's tree resource, its conditions, and the activities that have been undertaken to care for the trees. Developing a repository of tree-related education and communication plans with easy access would be a valuable tool to many communities.

\section{Natural Resource Issues and Community Forestry Programs}

Missourians value the state's natural resources but feel that not enough is being done to adequately address several key issues. Notably, survey respondents felt that the issues of managing stormwater runoff and making sure fewer trees are lost during development were inadequately addressed. This documented concern could perhaps be a springboard to securing community support to address issues.

Survey respondents showed overwhelming support for caring for new trees after planting, removing trees that might break and cause injury or property damage, and planting trees. This could be interpreted as a concern to care for a community's existing tree resource and then to replace what has been lost. The idea of conducting an inventory to assess current tree conditions and having a tree law that defines the community's responsibility for tree care and maintenance received much less support.

A plan for communicating the condition, existing maintenance needs, number, and location of existing trees; city departments responsible for work; the backlog of work; the reason for backlog (reduced budget, storm damage, etc.); and sources for further information would be constructive in most Missouri communities. Sharing current research finds pertaining to people's perceptions and 
behaviors regarding nature in cities should be a major focus of any communications plan. Many avenues of delivery should be explored, including media kits, general public programs, development of publications, and production of video and/or television segments. A concerted effort should be made to strengthen partnerships with local garden centers and landscape/nursery associations to facilitate the sharing of information. Cost-share dollars from MDC should continue to be made available to communities to fund educational efforts and training that focus on trees.

\section{The Hypothetical Tree Fund}

Residents in communities with a population of 50,000, in the St. Louis and Kansas City suburbs, and the cities of St. Louis and Kansas City show strong support for a tax of $\$ 5$ or less to support a tree fund. When pursuing passage of such a ballot issue, a promotion plan that carefully considers the amount of the tax, community responsibility for trees, and tree condition should be developed. These factors all play heavily into an individual's decision to support a fund dedicated to tree care in a community. A plan that addresses the concern of "other community priorities/ needs" cited by many "no" voters would make the ballot issue much more compelling.

Survey results show that only $11 \%$ thought that people in their community (other than themselves) would be willing to pay more in taxes for better tree care, yet over half of respondents said that they themselves would be willing. Many individuals who would support such an initiative feel as if they are the only one who does.

In addition, more attention and analysis needs to be given to the differences between the higher willingness to pay of larger and suburban communities and the lower willingness to pay of smaller communities. Groninger et al. (2002) noted that urban forestry has "traditionally been confined to large cities and their suburbs." Both educational and programmatic efforts will need to be better focused on smaller communities if both the quality of their urban forest resource and the level of interest of their residents are to be increased.

\section{Tree Preservation Ordinance}

Survey findings show support for passage of tree protection ordinances. Missourians in communities with a population greater than 5,000 showed a marked concern to protect or replace trees during development. As urban sprawl and community growth and expansion continue, the issues of reduced number of trees and the associated impact on property values, stormwater runoff, and reduced aesthetics become important. When pursuing passage of such an ordinance, a plan identifying key messages and a schedule of implementation should be developed. The impact on these three key concepts would be important to publicize when attempting passage of a tree preservation ordinance.
The measure would be more likely to pass if the issue of "development costs" could be framed in a convincing manner. This could be done by outlining the benefits of a shaded residence and the positive financial impact that trees have on businesses. Such information may shift some of the "no" voters to a positive position.

\section{Tree City USA}

The Tree City USA program is publicized by The National Arbor Day Foundation as a way to "make a strong contribution to your community's pride." Survey results clearly show that the majority of Missourians are unaware whether their community has achieved certification as a Tree City USA. Consequently, it seems that such certification plays a very small role in building community pride.

Despite this lack of recognition, Tree City USA certification is a valuable goal for every community regardless of size. The four standards a community must meet to earn certification provide structure for a successful and sustainable community forestry program. Those communities that achieve certification should take steps to better inform residents of their achievement. The current recognition tools, which include a Tree City USA flag, highway road signs, decals, hats, and patches, do not seem to be enough to inform residents of the community's achievement. Further thought needs to be given to developing new tools and to making better use of today's technology to share information.

Missourians value their natural resources, have strong beliefs about what should be done to care for the trees in their communities, and are even willing to approve various ballot measures to address tree-related concerns. They feel that not enough is being done to adequately address managing stormwater runoff and making sure fewer trees are lost during development. Yet many Missourians seem to lack a grasp of what specifically their community has undertaken to address tree related issues and concerns. Community forestry managers should consider development of a communications plan with a schedule of implementation in order to secure public support for the management of a community's tree infrastructure.

\section{LITERATURE CITED}

Baker, F. 1993. Monitoring the urban forest —Case studies and evaluations. Environ. Monitor. Assess. 26(2-3):153163.

Baruch, Y. 1999. Response rate in academic studiesA comparative analysis. Hum. Relat. 52(4):421438.

Boyle, K. 2003. Contingent valuation in practice, pp. 111169. In Champ, P., K. Boyle, and T. Brown (Eds.). A Primer on Nonmarket Valuation. Kluwer Academic Publishers, Dordecht, The Netherlands.

Connelly, N, T.L. Brown, and D.J. Decker. 2003 Factors affecting response rates to natural resource-focused mail 
surveys: Empirical evidence of declining rates over time. Soc. Nat. Resour. 16:541-549.

Council of Tree \& Landscape Appraisers (CLTA). 1992. Guide for Plant Appraisal (8th ed). International Society of Arboriculture, Champaign, IL. 41 pp.

Dickerson, S., J. Groninger, and J. Mangun. 2001. Influences of community characteristics on municipal tree ordinances in Illinois, U.S. J. Arboric. 27(6):318-325.

Dillman, Don A. 2000. Mail and Internet Surveys: The Tailored Design Method. John Wiley \& Sons, New York, NY.

Dwyer, J., H. Schroeder, J. Louviere, and D. Anderson. 1989. Urbanites willingness to pay for trees and forests in recreation areas. J. Arboric. 15(10):247-252.

Elmendorf, W., and A. Luloff. 2001. Using qualitative data collection methods when planning for community forests. J. Arboric. 27(3):139-151.

Gartner, J., T. Treiman, and T. Frevert. 2002. Missouri urban forest-A ten-year comparison. J. Arboric. 28(2):76-83.

Groninger, J., D. Close, and C. Basman. 2002. Can small, rural communities practice urban forestry? J. For. 100(1):23-28.

Kwak, S., S. Yoo, and S. Han. 2003. Estimating the public's value for urban forest in the Seoul metropolitan area of Korea: A contingent valuation study. Urban Stud. 40(11):2207-2221.

Lohr, V., C. Pearson-Mims, J. Tarnai, and D. Dillman. 2004. How urban residents rate and rank the benefits and problems associated with trees in cities. J. Arboric. 26(6):319-325.

Lorenzo, A., C. Blanche, Y. Qi, and M. Guidry. 2000. Assessing residents' willingness to pay to preserve the community urban forest: A small-city case study. J. Arboric. 30(1):28-35.

Mitchell, R., and R. Carson. 1989. Using Surveys to Value Public Goods: The Contingent Valuation Method. Resources for the Future, Washington, DC.

National Arbor Day Foundation. 2005. Tree City USA. www.arborday.org/programs/TreeCityUSA.cfm (accessed 7/28/05).

Nowak D.J., M. Noble, S. Sisinni, and J. Dwyer. 2001. People \& trees-Assessing the U.S. urban forest resource. J. For. 99(3):37-42.

Rocca, J.P. 1992. Survey shows need for city trees. Missouri Municipal Review. 57(4):20-21.

Treiman, T., and J. Gartner. 2004. Community forestry in Missouri, U.S.: Attitudes and knowledge of local officials. J. Arboric. 30(4):205-213.
Treiman, T., and J. Gartner. 2005. Urban Forestry in Missouri Communities: Attitudes and Knowledge of Missouri Citizens. An Attitude Survey and Analysis for the Missouri Department of Conservation. Missouri Department of Conservation Jefferson City, MO. 55 pp.

Tyrväinen, L., and H. Väänänen. 1998. The economic value of urban forest amenities: An application of the contingent valuation method. Landsc.Urban Plann. 43:105-118.

\author{
${ }^{1 *}$ Natural Resource Economist \\ Resource Science Division \\ Missouri Department of Conservation \\ 1110 S. College Ave. \\ Columbia MO 65201, U.S. \\ tom-treiman@mdc.mo.gov \\ ${ }^{2}$ Field Program Supervisor \\ Forestry Division \\ Missouri Department of Conservation \\ P.O. Box 180 \\ Jefferson City, MO, 65102, U.S.
}

*Corresponding author. 
Résumé. Une enquête autonome qui a été faite auprès de gens choisis aléatoirement au sein de 44 communautés du Missouri a permis de découvrir que la plupart des gens étaient très préoccupés par rapport à la qualité des ressources naturelles et aussi à propos d'avoir des arbres le long des rues et dans les parcs. Les répondants avaient le sentiment que le Missouri n'était pas efficace pour s'assurer qu'un minimum d'arbres soit coupé lors de développements et pour gérer l'érosion par l'eau lors de pluies abondantes. Les résidants des communautés de 50000 habitants et plus au sein des banlieues et des villes de St-Louis et Kansas City ont exprimé un support très fort envers l'établissement d'un fond dédié au moyen d'une taxe $5 \$$ ou moins. Les gens des communautés de plus de 5000 habitants du Missouri ont montré un intérêt pour supporter la protection ou le remplacement des arbres lors de développements, et ce par l'adoption d'une ordonnance de préservation des arbres. Les répondants manquaient de connaissance à propos de leur programme local pour les arbres, et ils ne pouvaient dire si leur communauté locale était certifiée Ville arborée américaine (Tree City USA) par la Fondation nationale du Jour de l'arbre. Généralement ces gens recueillent leurs informations sur les arbres auprès de leur centre-jardin local. Les résultats de cette enquête, amalgamés avec ceux récents effectués par les gestionnaires locaux des arbres ainsi qu'avec les inventaires d'arbres, sont utilisés pour émettre des recommandations auprès des responsables des agences de l'état pour la gestion des forêts au sein des communautés.

Zusammenfassung. Eine selbstverwaltete Umfrage unter zufällig ausgewählten Teilnehmern in 44 Gemeinden in Missouri ergab, daß die meisten Anwohner große Betroffenheit zeigen über der Qualität der natürlichen Resourcen und dass sie Bäume in Parks und Straßen haben. Die Teilnehmer fanden, dass der Staat Missouri nicht gut genug handelt in Bezug auf Baumverlust während Bauarbeiten und in der Kontrolle von Überschwemmungsschäden. Die Anwohner von Gemeinden mit einer Population von mehr als 50.000, im Umland von St. Louis und Kansas City, und in deren Stadtbezirken zeigten eine starke Unterstützung für eine über- geordnete Gründung eines Baum Fonds, finanziert durch eine Steuer von maximal \$5. Anwohner von Gemeinden mit einer Population von mehr als 5000 unterstützten die Idee zur Etablierung einer Baumschutzverordnung zum Schutz von Bäumen während der Bauphasen. Sie hatten wenig Kenntnisse über die bestehenden Baumverordnungen in ihrer Gemeinde und konnten nicht korrekt angeben, ob ihre Gemeinde zertifiziertes Mitglied bei TREE CITY USA ist. Sie beziehen ihr Wissen höchstwahrscheinlich von lokalen Gartencentern. Die Ergebnisse der Umfrage zusammen mit anderen neueren Umfragen von Forstverwaltungen und Straßenbaumkatastern werden genutzt, um Empfehlungen für staatliche Baumbetreuungsagenturen zu erarbeiten.

Resumen. Un estudio de respondientes administrado en forma aleatoria en cuarenta y cuatro comunidades de Missouri encontró que la mayoría de los Misourianos estuvieron muy preocupados acerca de la calidad de los recursos naturales, y de tener árboles en calles y parques. Los contestadores sienten que en Missouri no se está haciendo lo apropiado para lograr que se pierdan pocos árboles durante los desarrollos, y en el manejo del escurrimiento de las tormentas. Los residentes en comunidades con una población de 50,000 o más, en los suburbios de St. Louis y Kansas City, y en las ciudades de St. Louis y Kansas City muestran fuerte apoyo para el tema de establecer árboles en base a impuestos de $\$ 5.00$ o menos. Los Misourianos en comunidades con una población mayor a 5,000 mostraron apoyo para la protección o reemplazo de los árboles durante el desarrollo a través de la aprobación de una ordenanza de preservación. Al carecer del conocimiento básico sobre los programas de los árboles de su comunidad, no podrían decir si su comunidad sería certificada por la National Arbor Day Foundation como una Tree City USA. Ellos son más propensos a buscar información de los árboles en su centro de jardinería local. Los resultados del estudio, junto con recientes trabajos de comunidades forestales oficiales e inventarios de árboles urbanos, son usados para hacer recomendaciones a agencias estatales encargadas del manejo de los bosques comunales. 